\section{State Help for Gliding}

REPLying to a question in the House of Commons on June 27, Sir Philip Sassoon, Under-Secretary of State for Air, stated that the Government has reached the conclusion that some measure of financial assistance to the gliding movement from the Air Votes is justified. This will probably take the form of assistance towards the formation and maintenance of a properly organised central gliding school, which is regarded as essential to the sound development of gliding, coupled with a small capitation grant to approved clubs in respect of each certificate taken out by their members. Details are not yet known, but will be worked out in conjunction with the various interests concerned. The proposal is that a sum of not more than $£ 5,000$ annually, for a fiveyear period in the first instance, shall be granted. Sir Philip expressed the hope that now that official recognition is to be accorded to the national importance of gliding, generous financial support will also be forthcoming from private sources in order to ensure the success of the movement.

\section{Zeppelin $L Z-129$}

A NEw Zeppelin airship, $L Z-129$, is now nearing completion in Germany (Science Service, June 6), and if satisfactory will be put into service as a sister ship to the Graf Zeppelin, now operating for the sixth season between Europe and Brazil. The eastbound crossing of the new ship is expected to take less than two days, and the return against head winds a little less than three days. The calculated range without refuelling is 8,000 miles. Although only slightly longer than the American Macon, at present the largest airship extant, $L Z-129$ will be considerably larger, with a gas capacity of $7,070,000$ cubic feet as compared with 6,500,000 of the Macon. On her trial flights this summer, she will be inflated with hydrogen gas. It is reported that the use of helium gas is being considered for normal passenger flights. The Diesel engines, totalling 4,400 horsepower, will be in gondolas attached outside the hull, with ladders permitting access to other parts of the ship as in previous Zeppelin designs. German aeronautical engineers have never accepted the recent American procedure of placing the engine compartments inside the 'hull' or skin. The accommodation includes two promenade decks, state-rooms for fifty passengers, running water and baths, and a special smoking room. Besides these appointments are quarters for a crew of 35 and space for a mail and freight load of ten tons.

\section{International Broadcasting Union}

The issue of World Radio of June 29 contains an account of the London meeting of the Union Internationale de Radiodiffusion, which was concluded on June 20, and also the report of the Council of the Union. The meeting was attended by seventy-three delegates, including representatives of the broadcasting organisations of twenty European countries, of the two great American chains of stations and of the Cuban broadcasting organisation; and, in addition, delegates from thirteen Europэan State administrations. The general assembly and business meetings were held at the Grosvenor House Hotel, but visits were arranged to such places of interest as the International Trunk Exchange of the G.P.O., to Broadcasting House and to two stations of the B.B.C. The report of the Council of the Union concerns the European wave-length situation, and such subjects as international programmes and their future arrangement, and the legal aspects of authors' rights. The impression of the Council is that, since the introduction of the Lucerne plan, the general situation in regard to broadcasting on the long wave. lengths has been appreciably improved by the partial application of certain recommendations made at Geneva in February. The situation is complicated by the presence in the long-wave band of the stations Luxembourg and Madona, which were not given long wave-lengths by the Lucerne conference. No solution of this difficulty can be found at present, but rocommendations were made to the Governments and broadcasting organisations concerned to re-examine the situation arising therefrom with the view of reaching an arrangement satisfactory to all the interested services.

THE report also states that 409 programmes of special interest or high artistic value were offered by members of the Union to their colleague organisations during 1933-34. Certain of these programmes, such as the relays of the bells of Bethlehem and the Byrd Antarctic Expedition, were accepted by members in various continents. The Union has decided to repeat, in some new form yet to be determined, the successful Christmas programme of 1933, wherein several European broadcasters contributed, by means of specially prepared records, seasonable expressions of goodwill from their respective countries. At the sitting of the new Council which terminated the London meetings, Vice-Admiral Sir Charles Carpendale, of the British Broadcasting Corporation, was elected president of the Union for the tenth successive time. The next meetings of the Council of the Union will be held in Switzerland in February 1935, while the next annual general assembly will be in Poland.

\section{Drinking Water and the Drought}

Details have been circulated of an emergency organisation which Imperial Chemical Industries, Ltd., Millbank, S.W.1, with the approval of the Ministry of Health, has set up to assist local authorities which may be experiencing difficulties with their supplies of drinking water. In many instances, owing to a shortage of the regular supply, water has to be obtained from other sources, the purity of which may be doubtful and below the usual standard. Such emergency supplies may, however, be rendered quite safe for domestic purposes provided they are first adequately treated and sterilised. Treatment with chlorine in some form is that generally employed, as it is efficient and comparatively simple in application, the four agents generally used being liquid chlorine, 'chloros', chloramine and 